\section{Whales of the World}

Nigel Bonner

Blandford Press, 1989, 192 pp., HB $£ 14.95$

This is an admirable summary of the natural history of whales, dolphins and porpoises, by a zoologist who is not only well qualified by his long service in the Antarctic but also unlike so many scientists, has a most pleasing writing style. In only 174 well illustrated pages he has managed to include much unusual information as well as being right up to date on both the behavioural and physiological adaptations of whales to their aquatic environment. Thus although even an experienced human pearl diver cannot hold his breath for more than $2 \frac{1}{2}$ minutes, a bottlenose whale can stay submerged for two hours, thanks to various complicated biochemical adaptations, such as storing oxygen in its muscles with the help of a specialized protein, myoglobin.

In some ways whales have become the archetypal animals of the modern world. The huge size of the baleen whales, their high intelligence, their harmlessness to man, and the brutal way in which man has preyed upon them and exterminated or almost exterminated many stocks: all these factors have influenced the increasing number of people who are appalled at the insensitive way in which mankind as a whole has treated and is still treating the planet. 'Save the Whales' has become a classic slogan of the environmental movement.

Nigel Bonner most percipiently describes the rake's progress by which the International Whaling Commission, set up to manage whale stocks in order to safeguard the whaling industry, was instead used by the short-sighted whalers to ensure the destruction of the stocks and the suicide of their own industry. From the 1860s onwards Book reviews stock after stock was systematically reduced to commercial extinction, first in the Arctic after Suend Foyn's invention of the explosive harpoon, and after 1925 in the Antarctic when another Scandinavian, Petter Sørlle, invented the slip-stem factory ship. From start to finish the story of international whale conservation has been 'too little, too late'.

Richard Fitter, Vice-President, FFPS

\section{Tropical Landshells of the World}

Brian Parkinson, with Jens Hemmen and Klaus Groh

Verlag Christa Hemmen, Weisbaden, Western Germany, 1987, 279 pp., DM 198

Although more than 1000 mollusc species now appear on regional, national and international lists of threatened and extinct species, this group of animals is still almost bottom of the league in terms of conservation priorities. Their lack of popular appeal and the dearth of specific information about which molluscs are threatened largely accounts for this. However, at last we have a book that makes a start at resolving both these problems.

The majority of threatened molluscs are terrestrial landsnails. To people in temperate lands, a snail is a small, dull, inconspicuous animal, best trampled underfoot before it lays waste to the lettuce seedlings. Yet the great rain forests of the world are home to thousands of beautiful snails, the shells of which rival any marine mollusc in colour, pattern and sculpture. The 77 plates in Brian Parkinson's book, most of them photographed by Chris Prior, provide a stunning display of their variety and jewellike brilliance. The famous Manus Island green snail is perhaps familiar to some people, as a result, unfortunately, of its popularity in trade. Fewer people will be familiar with the small, colourfully striped
Polymita snails from Cuba or the vast numbers of varied Philippine snails.

Tropical Landshells of the World is the first popular book on tropical land snails since the 1940s and it fills a gaping hole. Introductory overviews of each of the main tropi cal malacological regions are followed by brief systematic accounts for each region and a useful bibliography of some 1000 references. also arranged regionally. The book does not profess to be a complete guide-with some 40,000 terrestrial mollusc species in the world, most of which are found in the tropics, this would be almost impossible. About 30 families are represented and the plates illustrate about 1000 species and subspecies. The authors stress that the taxonomy adopted is a compromise between current opinionsmolluscan taxonomy is still extremely fluid, and although the specialists may not agree with some of the names in this book, for the general reader such problems are outweighed by the value of having so much information in a single volume.

But perhaps of greatest interest to the Oryx readership, is the attention that the authors draw to the plight of so many species. As Brian Parkinson points out in his foreword, landsnails are among the animals most vulnerable to the disappearance of the rain foreststheir powers of dispersal are extremely limited, and their life histories are usually finely attuned to the particular microclimate within their patch of forest. The regional overview sections make depressing reading '. . . Unfortunately, many of these interesting snails have now gone the way of the Dodo, as nearly all the ebony forests that once covered the island have been cleared to make way for sugar cane.' This refers of course to Mauritius, and similar stories are told about the Philippines, Mada- 